\begin{tabular}{ccc}
\hline International Journal of Engineering \& Technology, $7(4.13)(2018) 214-220$ \\
SPC \\
Website: www.sciencepubco.com/index.php/IJET \\
Research paper
\end{tabular}

\title{
Material selection and design analysis of multi-purpose disposable safety syringe
}

\author{
Mohd Nasri Ishak ${ }^{1,2}$, Abd Rahim Abu Talib ${ }^{1 *}$, Mohammad Yazdi Harmin ${ }^{1}$ \\ ${ }^{1}$ Department of Aerospace Engineering, Faculty of Engineering, Universiti Putra Malaysia, 43400 Serdang, Selangor, Malaysia \\ ${ }^{2}$ Selia-Tek Industries Sdn. Bhd, No 18, JalanTeknologi 3/5, PJU 5, Taman Sains Selangor, Kota Damansara, Selangor, Malaysia \\ *Email:abdrahim@upm.edu.my
}

\begin{abstract}
Current design of safety syringes requires two handed operation and additional processes which is not similar to the normal syringes. Due to this concern, a new design of safety syringe is introduced in order to produce a safety syringe which allows a single-handed operation and similar to the operation of a normal syringes. This paper presents the material selection process and design analysis of a newly developed multi-purpose disposable safety syringe. Based on the design analysis, the force which needed to dismantle the nozzle is found to be $20 \mathrm{~N}$ and this value is practical for the end users. The finite element analysis had also shown that the design concept is safe and has safety feature for the user to use. In addition, copolymer is proven as the best material selection for safety syringe production.
\end{abstract}

Keywords: Design And Material; Analysis; Normal Syringe; Safety Syringe.

\section{Introduction}

Syringe is a one of the important components in the hospital and clinical devices and plays a key role in the medical and treatment. There are several types of syringe being used, with the most widely used are hypodermic and oral syringes. The usage of syringes sometimes can lead to cross infection and needle stick injuries due to the wrong method of usage and related to the design itself. In normal practice, there are two main problems while using syringe, the first is reuse of syringes and the second is needle stick and sharp injuries [1]. Nowadays, reuse of needles and syringes has caused spread of diseases, including risk of transmission of blood borne pathogens like human immunodeficiency virus (HIV), hepatitis B virus, (HBV) and hepatitis $\mathrm{C}$ virus (HCV). One of the accidents that may occur frequently while using syringe is the needle stick and sharp injuries [2]. The needle stick injuries are wounds caused by needles that accidentally puncture the skin. The Ministry of Health Malaysia defines needle stick injury as injury caused by suture or hollow-bore needle or sharp instrument [3].

Needle stick injuries are hazardous for people who work with the hypodermic syringes and other needle equipment. These injuries can occur at any time when people use, disassemble, or dispose of needles. When needles are not disposed of properly, it can become concealed in linen or garbage and injure other workers who encounter them unexpectedly [4]. In order to prevent any accidental injuries, the transmission of blood borne infections from contaminated needles and exposure to hazardous bodily fluid, a syringe with safety features or known as safety syringe has been invented [5]. Though many single use safety syringes have achieved public acceptance and commercial success in the marketplace, there are some single use syringes with various problems. In addition, there are some factors that may need to be considered such as their sophisticated design and high cost of contemporary components.
According to the market survey in Malaysia [6], safety syringe has to maintain the same procedure as normal syringe. Even though there are a variety of safety syringes available in the market, they do not fulfil the basic requirements of the medical practices. Due to this concern, a new design improvement of safety syringe is introduced to enhance the design of an existing safety syringe. Table 1 summarizes the earlier development of safety syringe. This paper presents the material selection process and the design analysis of a newly developed multi-purpose disposable safety syringe. Analysis on design and material selection have been carried out in order to find the suitable material. The newly developed design system will enable the user to use it single handedly and easy to be disabled after usage.

\section{Materials and methods}

\subsection{Materials selection}

For the syringe in industries, most of the polymers used are the polypropylene (PP) and polyethylene (PE) because the main material is polymer. Selia-Tek Medical Sdn. Bhd., a company that produces syringe products, has used the polypropylene (PP) as the raw material of the syringe body. It is very important to study the properties of the material that it will be used in this research. As stated before, the main material of the syringe is polypropylene. Polypropylene itself has two types of material, which are copolymer and homopolymer. The actual process of industries should be considered in order to select the best material. Thus, the best solution is to do the material sample testing, getting the data and doing research on it. The important thing of this investigation is to study the stress-strain behaviour of copolymer and homopolymer. Furthermore, the stressstrain data is also needed in SOLIDWORK analysis data. 
Table 1: Development of safety syringe

\begin{tabular}{|c|c|c|c|}
\hline Patent & Mechanism & Advantages & Disadvantages \\
\hline US 6,979,314 B2 [7] & $\begin{array}{l}\text { Before: Connector will be locked together } \\
\text { with the notch of the connecting chamber. } \\
\text { After: Needle detach with the barrel } \\
\text { mouth by pulling the plunger. }\end{array}$ & $\begin{array}{l}\text { - The needle detach from the } \\
\text { barrel } \\
\text { - Protect from needle injury. }\end{array}$ & $\begin{array}{l}\text { - Additional procedure which } \\
\text { user needs to twist the plunger } \\
\text { to lock the notch. } \\
\text { - Process of needle disposal (to } \\
\text { separate metal \& plastic) not } \\
\text { easy because the needle is in } \\
\text { the barrel. }\end{array}$ \\
\hline US 6,413,236 B1 [8] & $\begin{array}{l}\text { Before: Vacuum created within the } \\
\text { variable vacuum compartment. } \\
\text { After: Needle automatically withdrawn } \\
\text { due to the vacuum created within the vari- } \\
\text { able vacuum compartment. }\end{array}$ & $\begin{array}{l}\text { - Needle detach from the barrel. } \\
\text { - Protect from needle injury. }\end{array}$ & $\begin{array}{l}\text { - Complex and high cost. } \\
\text { - Difficult to separate metal and } \\
\text { plastic for disposal process. } \\
\text { - No multitasking usage. }\end{array}$ \\
\hline US 5,938,641 [9] & $\begin{array}{l}\text { Before: Male piston will be pushed into } \\
\text { the female cavity and stuck with the nee- } \\
\text { dle ferrule. } \\
\text { After: Needle detaches by pulling the } \\
\text { plunger and the piston will pull out the } \\
\text { needle ferrule together. }\end{array}$ & $\begin{array}{l}\text { - Needle detach from the barrel. } \\
\text { - Protect from needle injury. }\end{array}$ & $\begin{array}{l}\text { - Complex and high cost. } \\
\text { - Size of barrel more bulky }\end{array}$ \\
\hline US 5,899,887 [10] & $\begin{array}{l}\text { Before: The detent will be entered the pul- } \\
\text { ing mechanism zone and click on the de- } \\
\text { tent. } \\
\text { After: Needle will be detached by pulling } \\
\text { the plunger backward. }\end{array}$ & $\begin{array}{l}\text { - Needle detach from the barrel. } \\
\text { - Protect from needle injury. }\end{array}$ & $\begin{array}{l}\text { - Difficult to separate metal } \\
\text { and plastic for disposal pro- } \\
\text { cess. } \\
\text { - Not multi-tasking usage. } \\
\text { - High cost. }\end{array}$ \\
\hline US 5,344,403 [11] & $\begin{array}{c}\text { Before: The hub will snug into the carrier } \\
\text { through bore. } \\
\text { After: The hub will carry and detach the } \\
\text { needle carrier by pulling the plunger. } \\
\text { Section of plunger can be easily broken } \\
\text { off }\end{array}$ & $\begin{array}{l}\text { - Needle detaches and saves in- } \\
\text { side the barrel }\end{array}$ & $\begin{array}{l}\text { - Complex and high cost. } \\
\text { - No multitasking. }\end{array}$ \\
\hline WO 2010/096879 [12] & $\begin{array}{c}\text { Before: First downward stroke the plunger } \\
\text { does not engage the needle assembly. } \\
\text { After: Second down stroke the plunger } \\
\text { compresses the gasket so that the plunger } \\
\text { travels further to engage the needle } \\
\text { assembly }\end{array}$ & $\begin{array}{l}\text { - The needle will be separated } \\
\text { from the barrel. } \\
\text { - Easy disposal process. }\end{array}$ & $\begin{array}{l}\text { - Needle detach upfront, } \\
\text { dangerous for patients. } \\
\text { - The needle can be detached } \\
\text { while the injection process } \\
\text { applied. }\end{array}$ \\
\hline Mohd Zabidi [13] & $\begin{array}{l}\text { A small ring etched at the bottom side of } \\
\text { the barrel will lock the plunger when a } \\
\text { "click" sound will be heard when the full } \\
\text { injection is completed. The plunger will } \\
\text { effectively break when it is pulled back. } \\
\text { So the syringe cannot be used for the sec- } \\
\text { ond time. }\end{array}$ & $\begin{array}{l}\text { - The syringe can only be used } \\
\text { once. } \\
\text { - Simple design and low cost. }\end{array}$ & $\begin{array}{l}\text { - Needle still exposed to the } \\
\text { user. } \\
\text { - Cannot remain as multitasking } \\
\text { syringe. } \\
\text { - Cannot use for blood taking. } \\
\text { - Two handed operation. }\end{array}$ \\
\hline $\begin{array}{c}\text { Basri [14] } \\
\text { and } \\
\text { Abu Talib et al.[15] }\end{array}$ & $\begin{array}{l}\text { The needle support is attached with the } \\
\text { barrel by the bone structured which will } \\
\text { support the needle support temporary. The } \\
\text { bone structures will only break if there is } \\
\text { additional force acting towards it. So, the } \\
\text { syringe cannot be used anymore because } \\
\text { of the detachable of the needle support }\end{array}$ & $\begin{array}{l}\text { - No additional procedure } \\
\text { - Multitasking }\end{array}$ & $\begin{array}{l}\text { - Complex design (mould can- } \\
\text { not be fabricated) } \\
\text { - High cost } \\
\text { - Not easy to produce }\end{array}$ \\
\hline
\end{tabular}

\subsection{Design improvement}

The concept is innovated from the brainstorming idea of prior art research of safety syringes. There are a lot of good ideas obtained from the existing safety syringe design. Basically, the main objective in designing a new design of safety syringe is to disable the structure of syringe right after being used. For the safety syringe design, here are some design specifications that are important which will give the guidance for the new concept of the syringe. Listed below are the customer requirements that need to be understood in producing a good design of safety syringe [16].

- High safety (should have high safety feature to protect the needle from injury before and after the usage of the safety syringe)

- $\quad$ Easy for disposal process (should be easy especially in separating the metal and the plastic of the syringe)

- Easy to retract the needle (should be easy to retract the needle from the barrel and not complicated)

- Easy handling (should be easy to handle and it should be one single handed operation, no additional procedure)

- Performance of the safety syringe (should perform as good as the conventional syringe)
- Multitasking use (for feeding, injecting medicine and blood taking)

- Low cost (the production and manufacturing cost should be low so that the price of the new design of safety syringe will be suitable enough).

For industries process, the requirements are as follow [16]:

- Simple mould design (not complex design)

- $\quad$ Easy to produce the product at actual industries process

- Cost of mould design is not high and expensive (cost of mould depend on the design of the mould)

- Material flow is easy to be controlled and monitored (production process)

- No leaking issue on volume of medicine

- Assembly process is at low cycle time for mass production industries.

Ishak et al. [16] have summarized the process flow of selecting the best design of safety syringe. It starts with the comparison between two previous design and come up with the morphological chart for a new design and then evaluate each design. Based on Ishak et al. 
[16], the third design is selected as the best design. Table 2, Table 3 and Table 4 present the summary of morphological chart, alternative design concepts for safety syringe and also evaluation table of idea concept respectively.

Table 2: Summary of morphological chart
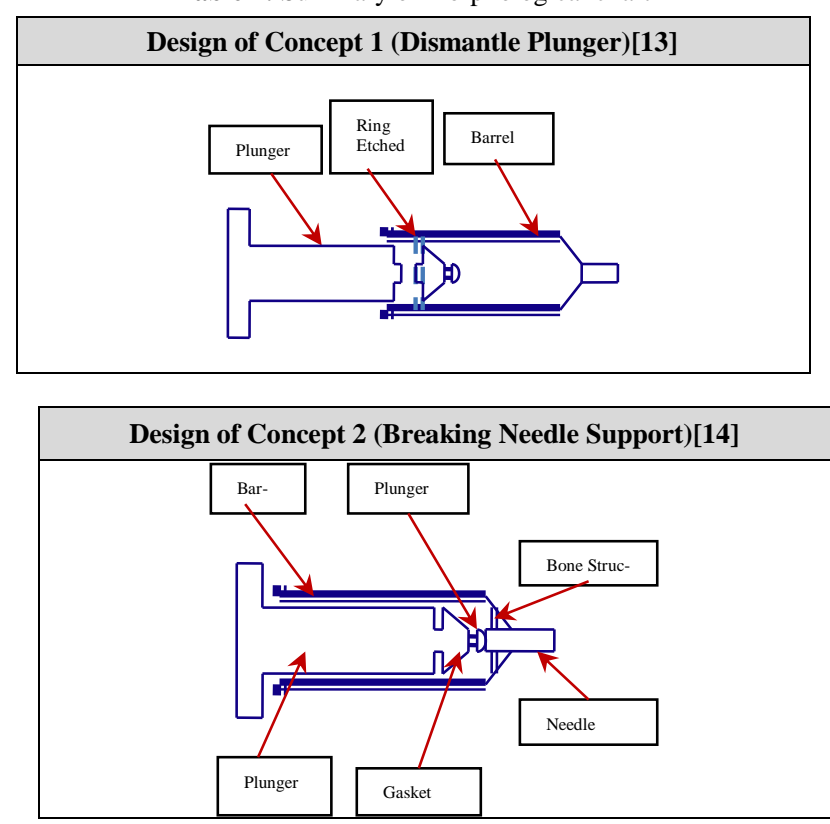

\begin{tabular}{|c|c|c|c|}
\hline \multicolumn{4}{|c|}{ Design of Concept 3 (Releasing Locking System) [16] } \\
\hline $\begin{array}{l}\text { Func- } \\
\text { tion }\end{array}$ & Idea 1 & Idea 2 & Idea 3 \\
\hline Plunger & $\begin{array}{l}\text { Remain the } \\
\text { same }\end{array}$ & $\begin{array}{l}\text { Remain the } \\
\text { same }\end{array}$ & $\begin{array}{c}\text { Additional } \\
\text { plunger head } \\
\text { at the end of } \\
\text { plunger }\end{array}$ \\
\hline Barrel & $\begin{array}{c}\text { Open at end as } \\
\text { socket to } \\
\text { nozzle } \\
\end{array}$ & $\begin{array}{l}\text { Open at end as } \\
\text { socket to } \\
\text { nozzle } \\
\end{array}$ & 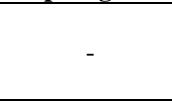 \\
\hline Gasket & No change & $\begin{array}{c}\text { Hollow gasket } \\
\text { to fix with } \\
\text { plunger }\end{array}$ & No change \\
\hline $\begin{array}{l}\text { Needle } \\
\text { support }\end{array}$ & $\begin{array}{l}\text { Locking at the } \\
\text { top of the barrel }\end{array}$ & $\begin{array}{c}\text { Locking at the } \\
\text { inside barrel }\end{array}$ & $\begin{array}{l}\text { Fixed with } \\
\text { barrel }\end{array}$ \\
\hline $\begin{array}{l}\text { Work- } \\
\text { ing } \\
\text { concept }\end{array}$ & $\begin{array}{l}\text { Plunger push } \\
\text { the nozzle }\end{array}$ & $\begin{array}{l}\text { Plunger push } \\
\text { the nozzle }\end{array}$ & None \\
\hline
\end{tabular}

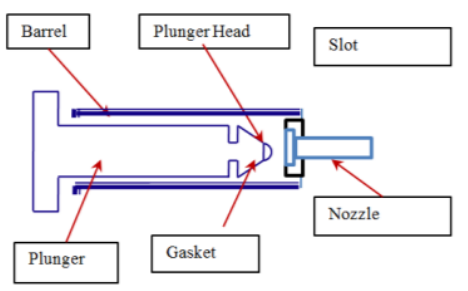

The survey has been conducted and 30 people from different professions participated as respondents for this survey [16]. The total number of respondents for each profession is ten people and their professions include the professionals, doctors and nurses. These three professions are selected due to their direct dealing with the product. The professionals from Selia-Tek Sdn. Bhd. Company are selected for their experience with regards to the process, design and production of syringe, while the doctors and nurses are selected as end users since they always deal with and use this product every day. The total mark of each design will be calculated, and the highest mark will indicate the best idea which followed the design specification.
Table 3: Alternative design concepts for safety syringe

\begin{tabular}{|c|c|c|c|}
\hline \multirow{2}{*}{ Function } & \multicolumn{3}{|c|}{ Result } \\
\hline & Idea 1 & Idea 2 & Idea 3 \\
\hline $\begin{array}{c}\text { Idea } \\
\text { concept }\end{array}$ & $\begin{array}{l}\text { Dismantle } \\
\text { plunger }\end{array}$ & $\begin{array}{c}\text { Breaking needle } \\
\text { support }\end{array}$ & $\begin{array}{l}\text { Releasing lock- } \\
\text { ing system }\end{array}$ \\
\hline $\begin{array}{l}\text { Working } \\
\text { mechanism }\end{array}$ & $\begin{array}{l}\text { Dismantle the } \\
\text { plunger head } \\
\text { from the barrel }\end{array}$ & $\begin{array}{c}\text { Needle holder } \\
\text { will be dismantle } \\
\text { forward }\end{array}$ & $\begin{array}{l}\text { The nozzle will } \\
\text { be dismantle } \\
\text { forward }\end{array}$ \\
\hline $\begin{array}{l}\text { Needle } \\
\text { safety }\end{array}$ & $\begin{array}{l}\text { Needle ex- } \\
\text { posed \& dan- } \\
\text { gerous for us- } \\
\text { ers }\end{array}$ & $\begin{array}{c}\text { Needle totally } \\
\text { detaches from the } \\
\text { barrel }\end{array}$ & $\begin{array}{l}\text { Needle totally } \\
\text { detaches from } \\
\text { the barrel }\end{array}$ \\
\hline $\begin{array}{l}\text { Hand us- } \\
\text { age }\end{array}$ & Two hands & Single & Single \\
\hline $\begin{array}{l}\text { Additional } \\
\text { procedure }\end{array}$ & $\begin{array}{l}\text { Yes } \\
\text { Use two } \\
\text { handed to pull } \\
\text { the plunger for } \\
\text { breaking pro- } \\
\text { cess }\end{array}$ & $\begin{array}{c}\text { No } \\
\text { Push plunger } \\
\text { with extra force } \\
\text { to break the nee- } \\
\text { dle support struc- } \\
\text { ture }\end{array}$ & $\begin{array}{c}\text { No } \\
\text { Push plunger } \\
\text { with extra force } \\
\text { to release lock- } \\
\text { ing system (dis- } \\
\text { mantle nozzle) }\end{array}$ \\
\hline $\begin{array}{c}\text { Needle } \\
\text { dismantle } \\
\text { process }\end{array}$ & Manually & Automatic & Automatic \\
\hline $\begin{array}{l}\text { Multitask- } \\
\text { ing }\end{array}$ & $\begin{array}{l}\text { Can only be } \\
\text { used for insert }\end{array}$ & Multitasking & Multitasking \\
\hline $\begin{array}{l}\text { Modifica- } \\
\text { tion }\end{array}$ & $\begin{array}{c}\text { Little changes } \\
\text { from original: } \\
\text { Barrel } \\
\text { Plunger }\end{array}$ & $\begin{array}{c}\text { Little changes } \\
\text { from original: } \\
\text { Barrel } \\
\text { Plunger head } \\
\text { Gasket } \\
\end{array}$ & $\begin{array}{c}\text { Little changes } \\
\text { from original: } \\
\text { Barrel } \\
\text { Plunger } \\
\text { Gasket } \\
\end{array}$ \\
\hline Cost & High & Low & Low \\
\hline $\begin{array}{c}\text { Disposable } \\
\text { process }\end{array}$ & $\begin{array}{c}\text { Easy } \\
\text { Needle } \\
\text { dismantles } \\
\text { manually } \\
\end{array}$ & $\begin{array}{c}\text { Easy } \\
\text { Automatic needle } \\
\text { dismantled }\end{array}$ & $\begin{array}{c}\text { Easy } \\
\text { Automatic nee- } \\
\text { dle } \\
\text { dismantled } \\
\end{array}$ \\
\hline $\begin{array}{c}\text { Simple } \\
\text { mould } \\
\text { design (not } \\
\text { complex) }\end{array}$ & $\begin{array}{c}\text { Complex } \\
\text { design (mould } \\
\text { can be } \\
\text { fabricated) }\end{array}$ & $\begin{array}{l}\text { Complex design } \\
\text { (mould cannot be } \\
\text { fabricated) }\end{array}$ & Simple design \\
\hline $\begin{array}{l}\text { Easy to } \\
\text { produce }\end{array}$ & No & No & Yes \\
\hline $\begin{array}{l}\text { Cost of } \\
\text { mould } \\
\text { design }\end{array}$ & High & High & Medium \\
\hline $\begin{array}{c}\text { Material } \\
\text { flow }\end{array}$ & Medium & Difficult & Medium \\
\hline $\begin{array}{c}\text { Leaking } \\
\text { issue }\end{array}$ & No & Yes & No \\
\hline $\begin{array}{l}\text { Assembly } \\
\text { process } \\
\text { (low cycle } \\
\text { time) }\end{array}$ & Long & - & Short \\
\hline
\end{tabular}

Table 4: Evaluation scheme for design concepts [17]

\begin{tabular}{|c|c|c|c|}
\hline $\begin{array}{l}\text { Point } \\
\text { Scale }\end{array}$ & Description & $\begin{array}{c}\text { Point } \\
\text { Scale } \\
\text { (weight) }\end{array}$ & Description \\
\hline 0 & Totally useless solution & \multirow{2}{*}{1} & \multirow{2}{*}{ Inadequate } \\
\hline 1 & Very inadequate solution & & \\
\hline 2 & Weak solution & \multirow{2}{*}{2} & \multirow{2}{*}{ Weak } \\
\hline 3 & Poor solution & & \\
\hline 4 & Tolerable solution & \multirow{3}{*}{3} & \multirow{3}{*}{ Satisfactory } \\
\hline 5 & Satisfactory solution & & \\
\hline 6 & $\begin{array}{l}\text { Good solution with a } \\
\text { few drawbacks }\end{array}$ & & \\
\hline 7 & Good solution & \multirow{2}{*}{4} & \multirow{2}{*}{ Good } \\
\hline 8 & Very good solution & & \\
\hline 9 & $\begin{array}{l}\text { Excellent (exceeds the } \\
\text { requirements) }\end{array}$ & \multirow[t]{2}{*}{5} & \multirow[t]{2}{*}{ Excellent } \\
\hline 10 & Ideal solution & & \\
\hline
\end{tabular}

Figure 1, Figure 2 and Figure 3 show the result of survey based on the questionnaire. The graphs show the answers for each of the three questions, respectively. Then, Table 5 shows the result evaluation table for selecting the best idea concept from the three ideas. In this table, each idea concept is evaluated based on the criteria importance from the design specification. Each design specification is 
assigned with importance based on the requirement. This result shows the average value only for all respondents.

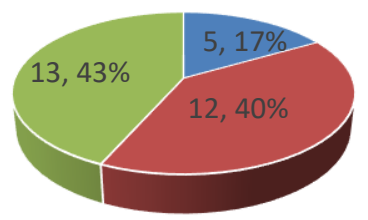

- Professionals - Doctors - Nurses

Fig. 1: The result for question number 1

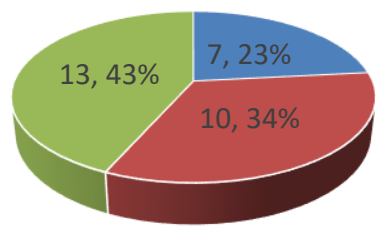

- 1- 5 Years - 6-10 Years - More than 10 years

Fig. 2: The result for question number 2

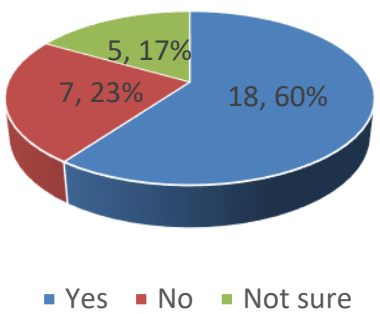

Fig. 3: The result for question number 3

Table 5: The result of evaluation table of the idea concepts

\begin{tabular}{|c|c|c|c|c|}
\hline No & CRITERIA & $\begin{array}{c}\text { FIRST } \\
\text { CONCEPT }\end{array}$ & $\begin{array}{c}\text { SECOND } \\
\text { CONCEPT }\end{array}$ & $\begin{array}{c}\text { THIRD } \\
\text { CONCEPT }\end{array}$ \\
\hline 1. & $\begin{array}{c}\text { High level of } \\
\text { safety }\end{array}$ & 8 & 8 & 8 \\
\hline 2. & Easy handling & 4 & 6 & 6 \\
\hline 3. & Low cost & 5 & 5 & 5 \\
\hline 4. & $\begin{array}{c}\text { Easy for disposal } \\
\text { process }\end{array}$ & 6 & 7 & 7 \\
\hline 5. & Performance & 4 & 7 & 7 \\
\hline 6. & $\begin{array}{c}\text { Easy to retract } \\
\text { needle }\end{array}$ & 5 & 6 & 6 \\
\hline 7. & Multitasking & 5 & 5 & 5 \\
\hline 8. & $\begin{array}{c}\text { Simple mould de- } \\
\text { sign }\end{array}$ & 6 & 3 & 6 \\
\hline 9. & Easy to produce & 4 & 3 & 6 \\
\hline 10. & $\begin{array}{c}\text { Cost of design } \\
\text { mould }\end{array}$ & 4 & 4 & 4 \\
\hline 11. & Material flow & 4 & 3 & 6 \\
\hline 12. & Leaking issue & 5 & 4 & 6 \\
\hline 13. & $\begin{array}{c}\text { Assembly process } \\
\text { (low cycle time) }\end{array}$ & 5 & 5 & 5 \\
\hline & TOTAL & $\mathbf{6 5}$ & $\mathbf{6 6}$ & $\mathbf{7 7}$ \\
\hline
\end{tabular}

The total mark for each design is calculated and the highest mark will indicate the best idea which followed the design specification. Due to these matters, the best idea concept of designing a safety syringe is by using the third idea, which is by releasing locking system based on the above evaluation tables. Figure 4 shows the selected geometry design of the safety syringe.

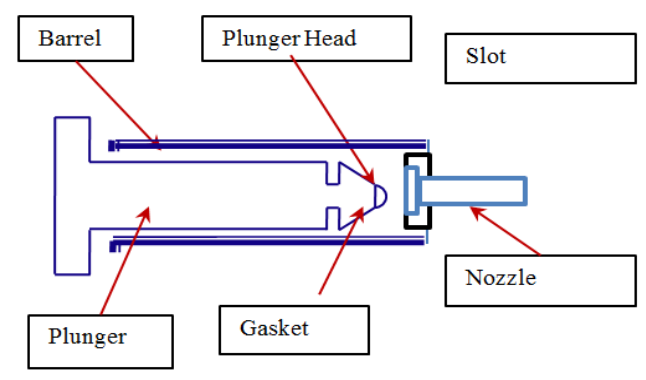

Fig. 4: Geometry design of safety syringe

\section{Results and discussion}

\subsection{CFD simulation}

A safety syringe consists of:

- The nozzle is designed with the slot structured inside the barrel to provide temporary joint of the nozzle

- The nozzle has stopper to prevent the nozzle from move inside the barrel

- The needle can only be detached upfront from the barrel

- The gasket made from a rubber that can compress when force is given

- The gasket has a hole in the middle of the piston to ensure the plunger head will push the nozzle and detached it.

The present invention will be fully understood from the detailed description given herein in Figure 5.

\begin{tabular}{|c|c|}
\hline PARTS & \multicolumn{2}{|c|}{ DIAGRAMS } \\
\hline Barrel & (4) \\
\hline Plunger & \\
\hline Gasket & \\
\hline Nozzle & \\
\hline
\end{tabular}

Fig. 5: Parts of safety syringe

\subsection{Assembly design}

Figure 6 shows the assembly of the new design of safety syringe which consist of four main components. The components are barrel, plunger, gasket and nozzle.

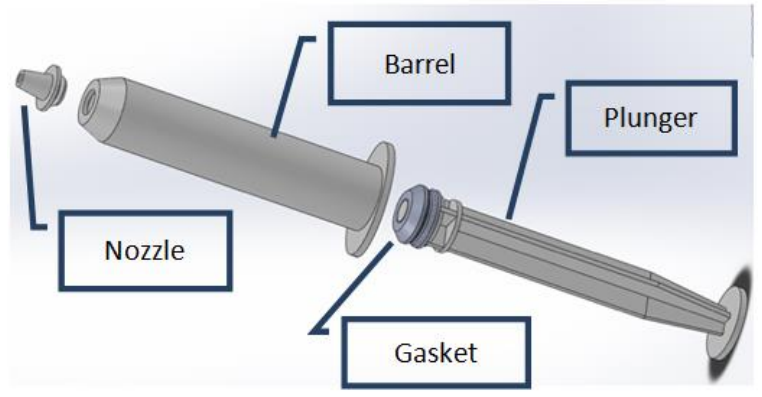

Fig. 6: Assembly of safety syringe 


\subsection{Function design}

The nozzle is attached with the barrel by assembling between the slot male (nozzle) and female (barrel) which function as locking system to support the nozzle temporary. The locking system will only release if there is additional force acting towards the bottom of the nozzle. So, the syringe cannot be used anymore due to the detachable of the nozzle. Figure 7 shows the before and after release locking mechanism.

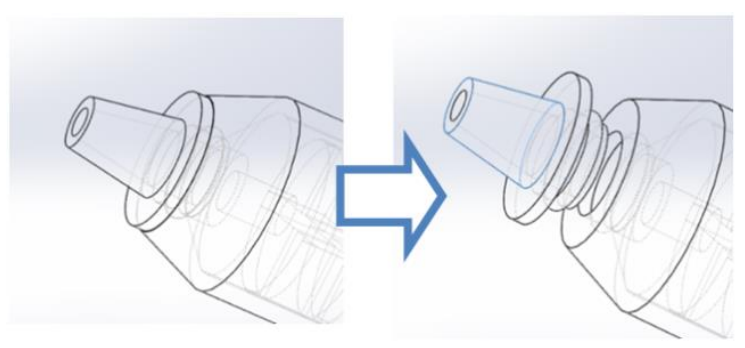

Fig. 7: Before and after releasing locking system

The new safety syringe is focusing on the nozzle detachable from the barrel. The nozzle of the syringe can be detached from the barrel if the additional force applied towards the plunger (Figure 8). The first down stroke of the plunger will make sure the fluid will be injected out from the barrel. The nozzle will not be detached from the barrel if the plunger is pushed with the normal force for medicine injection. It can only be detached if the additional force is given towards the plunger which will compress the gasket in front of the plunger. So, when the gasket is compressed, the plunger head will move forward and will pushed the nozzle to detach it from the barrel. It means that, the needle will retractable from the syringe and will ensure the syringe can only be used once. Figure 9 provides the summary of operational safety syringe for detail explanation.

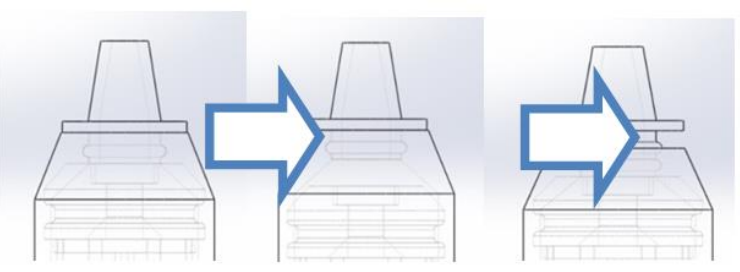

Fig. 8: Detail view of the dismantle process

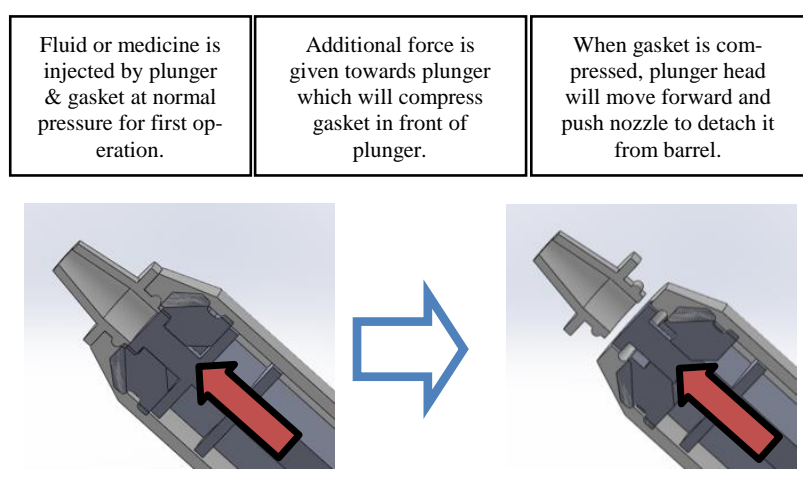

Fig. 9: Summary of the operation process

\subsection{Materials selection}

In this section, two kinds of materials polypropylene, which are homopolymer and copolymer, have been tested in order to select the best material for safety syringe. Basically most of syringe in industry used polypropylene materials which are for structure of barrel and plunger. It is because polyolefin (polypropylene and polyethylene) has high molecular weight hydrocarbons. It also has a break resistant, non-toxic and non-contaminating [18]. Furthermore, polypropylene is biocompatibility. Biocompatibility is very important to enhance healing functions without causing injurious, negative physiological, allergic or toxic reactions [19]. Here, a comparison of polypropylene materials, which are homopolymer and copolymer, has been carried out in order to see the effect of materials towards the minimum load for dismantling the nozzle.

The detail of comparison between these two types of material is as shown in Table 6 . One interesting finding is that homopolymer is the most widely utilized that offers a high strength to weight ratio, stiffer and stronger than copolymer. This result may be explained by the fact that different value of slope for both materials. Slope of the curve represent the Young's modulus of the material.

Table 6: Comparison between copolymer and homoplymer [20]

\begin{tabular}{|l|l|l|}
\hline Polypropylene & Copolymer & Homopolymer \\
\hline Type & $\begin{array}{l}\text { Consists of more than } \\
\text { one kind of monomers }\end{array}$ & $\begin{array}{l}\text { Consists of only one } \\
\text { kind of monomers }\end{array}$ \\
\hline Density & $0.90 \mathrm{~g} / \mathrm{cm} 3$ & 0.91 to $1.20 \mathrm{~g} / \mathrm{cm} 3$ \\
\hline Elongation & $12 \%$ & 3.3 to $10 \%$ \\
\hline $\begin{array}{l}\text { Flexural Modu- } \\
\text { lus }\end{array}$ & $1.3 \mathrm{GPa}$ & 1.5 to $7.0 \mathrm{GPa}$ \\
\hline $\begin{array}{l}\text { Strength-to- } \\
\text { weight }\end{array}$ & 32 to $37 \mathrm{kN} \cdot \mathrm{m} / \mathrm{kg}$ & 40 to $83 \mathrm{kN} \cdot \mathrm{m} / \mathrm{kg}$ \\
\hline UTS & 29 to $33 \mathrm{MPa}$ & 36 to $100 \mathrm{MPa}$ \\
\hline $\begin{array}{l}\text { Tensile strength } \\
\text { (yield) }\end{array}$ & $410 \mathrm{~kg} / \mathrm{cm}^{2}$ & $320 \mathrm{~kg} / \mathrm{cm}^{2}$ \\
\hline $\begin{array}{l}\text { Rockwell } \\
\text { hardness }\end{array}$ & $100 \mathrm{R}$-scale & $80 \mathrm{R}$-scale \\
\hline Melt flow rate & $20 \mathrm{~g} / \mathrm{min}$ & $25 \mathrm{~g} / \mathrm{min}$ \\
\hline Melting point & $150^{\circ} \mathrm{C}$ & $165^{\circ} \mathrm{C}$ \\
\hline
\end{tabular}

The Young's modulus of the materials could be estimated by taking the slope of the line region of elastic deformation. Young's modulus of copolymer is $1790.92 \mathrm{MPa}$ while that for homopolymer is 2976.23 MPa. The tensile strength of a typical homopolymer is about $15 \%$ higher than that of the corresponding copolymer and the modulus is nearly $13 \%$ greater. Copolymer tends to have better stress crack resistance and low temperature toughness than homopolymer at the expense of quite small reductions in other properties. Figure 10 shows the stress and strain curve comparison between homopolymer and copolymer material.

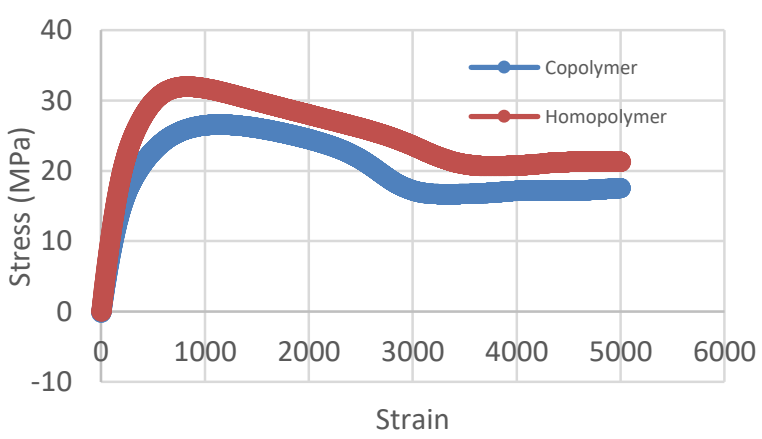

Fig. 10: Stress and strain curve comparison between homopolymer and copolymer materials

One have to consider the actual process of producing the syringe (injection moulding and material flow) instead of the physical properties of the syringe in order to select the best material for the safety syringe production. Copolymer offers better material flow rate compared to homopolymer, copolymer is $20 \mathrm{~g} / \mathrm{min}$ meanwhile homopolymer is $25 \mathrm{~g} / \mathrm{min}$. In injection moulding process, it is important to have a good material flow rate so that it is easier to produce the part product without defects such as flashing (burr) and air trapped (bubble) appearance and also easy to product release. Another important finding is that, the copolymer also has a lower melting point temperature than homopolymer, which is good to save the utilities cost. The results in a melting point for the copolymer that 
is about $10^{\circ} \mathrm{C}$ lower than homopolymer. Thus the copolymers potentially can be processed at a lower melt temperature. This result is in agreement with Sepe's findings [21], which showed copolymer has reduced the crystallininity and this led to lower melting temperature than homopolymer. Based on this premise, polypropylene copolymer is selected due to this material is suitable for actual process and mass production.

In this study, selection of material for safety syringe also has been done. Copolymer is proven as the best material between both homopolymer and copolymer. This can been seen by comparing the graph based on tensile test and also in line with the data theoretically.

\subsection{Design analysis}

Based on the new design of safety syringe, the most critical component that plays an important role in ensuring the design work is the slot assembly. The nozzle is designed with the slot structured inside the barrel to provide temporary joint of the nozzle. The assemble of female and male slot is not too fitted in order to easy the dismantle of the nozzle and at the same time it is not too loose to avoid the leakage issue to occur. The moment the extra force is given towards the nozzle, it will be dismantled. So, this analysis is significant in order to obtain the minimum force needed to dismantle and to make sure the design works.

Simulation analysis has been carried out in order to obtain the minimum force required for plunger head to dismantle the nozzle. In this case, nonlinear stress analysis which has been selected as the best analysis is used for obtaining the best force for the nozzle to be dismantled (see Figure 11). So, the SOLIDWORKS software has been used in order to obtain the best force which needed to dismantle the nozzle (see Figure 12). The analysis will start with the data key in from material analysis into the table stress strain. Then the result of the both material will be compared by using the SOLIDWORKS analysis. Figure 13 shows finite element analysis of the safety syringe drawing.

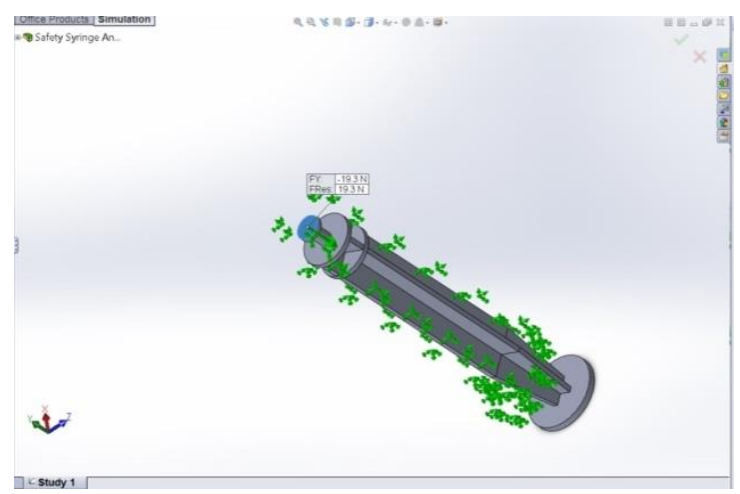

Fig. 11: Analysis for plunger

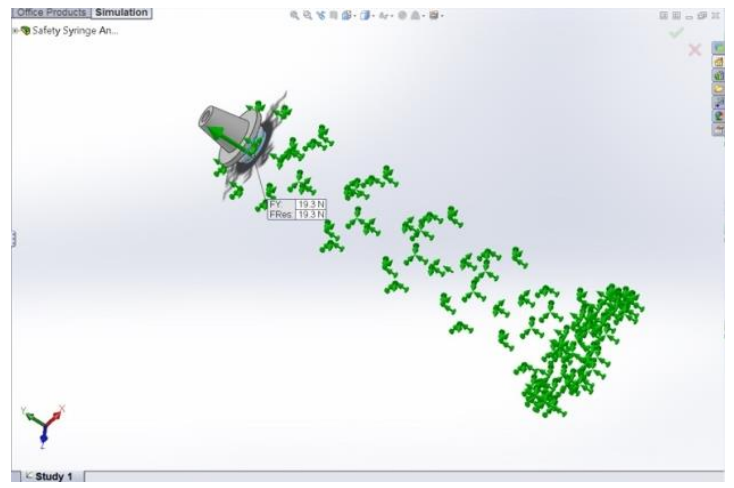

Fig. 12: Analysis for nozzle

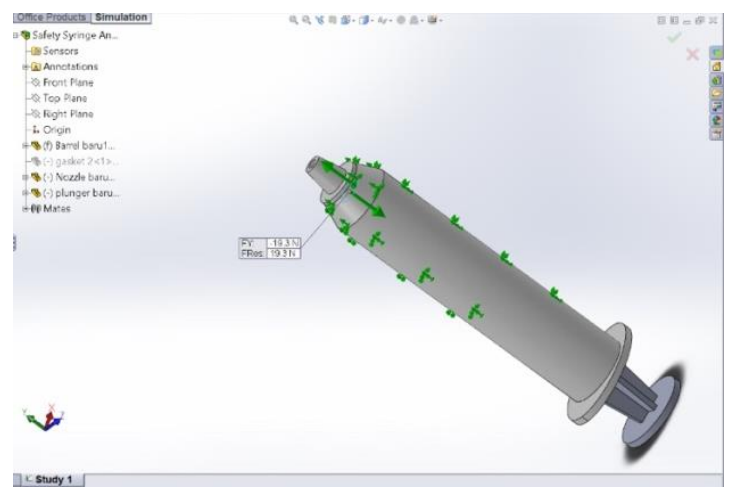

Fig. 13: Finite element analysis of safety syringe

Figure 14 shows the graph of the contact/friction force versus time based on finite element analysis of the SOLIDWORKS software. Referring to the simulation analysis given, it shows that the minimum force needed to dismantle the nozzle is about $19.30 \mathrm{~N}$.

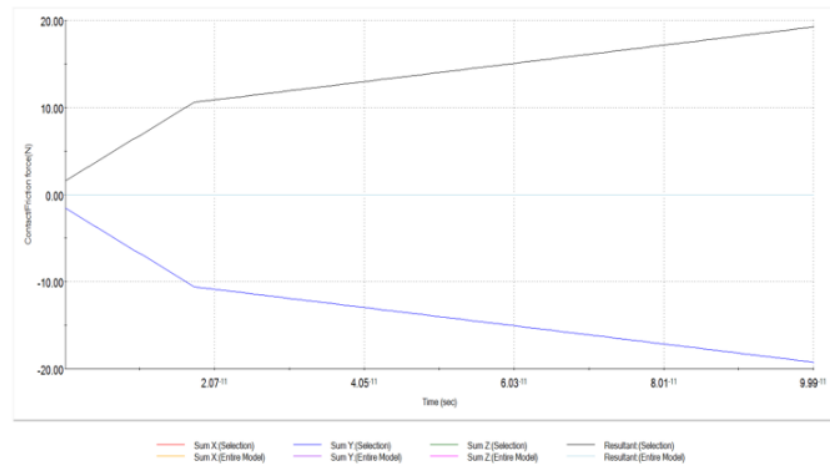

Fig. 14: Contact force of safety syringe

The results were compared with the study obtained by Claudio [22]. A study of injection pressure by anaesthesiologist during simulated peripheral nerve block has been conducted towards 30 anaesthesiologists in order to observe the inconsistent injection force of the syringe. During a steady injection rate, all anaesthesiologists perceived an increase in the force required to inject, even with minor pressures changes $(0.6 \pm 0.3 \mathrm{psi})$ or $\left(0.004 \pm 0.002 \mathrm{~N} / \mathrm{mm}^{2}\right)$. The result shows $21(70 \%)$ using a force that resulted in pressure greater that $20 \mathrm{psi}(0.138 \mathrm{~N} / \mathrm{mm} 2) ; 15(50 \%)$ used a force greater than 25 psi $\left(0.172 \mathrm{~N} / \mathrm{mm}^{2}\right)$ and $3(10 \%)$ exerted pressure greater than $30 \mathrm{psi}$ $\left(0.206 \mathrm{~N} / \mathrm{mm}^{2}\right)$ [22].

Based on the analysis, the minimum force needed to dismantle the nozzle is $19.30 \mathrm{~N}$. With the area of nozzle is $1.77 \mathrm{~mm}^{2}$, the pressure can be calculated using Eqn. 1, where $\sigma$ is pressure in $\mathrm{Pa}, F$ is load in $\mathrm{N}$ and $A$ is cross sectional area of sample in $\mathrm{mm}^{2}$.

$$
\sigma=\frac{F}{A}=11.56 \mathrm{~N} / \mathrm{mm}^{2}
$$

Due to this matter, the analysis shows that the design will not fail during injection process. It is because the statistical study shows the highest pressure during injection process is around 30 psi or 0.206 $\mathrm{N} / \mathrm{mm}^{2}$ [22] and the minimum pressure for the nozzle to be dismantled is $11.56 \mathrm{~N} / \mathrm{mm}^{2}\left(0.004 \pm 0.002 \mathrm{~N} / \mathrm{mm}^{2}\right)$. This shows the design is secure than the statistical study and it is safe to be used.

\section{Conclusion}

As a conclusion, this project has achieved its objective which is to design and fabricate a safety syringe with simple and non-complex design. This new design of Multi-purpose Disposable Safety Syringe is basically has a concept of dismantling the nozzle by giving extra force toward the bottom of the nozzle. Moreover, this design is following all the criteria and design specifications that need to be 
understood in producing a good design of safety syringe. Based on the design analysis, the force which is needed to dismantle the nozzle is about $20 \mathrm{~N}$ and this value is practicable for the end users. The finite element analysis had also shown that the design concept is safe and has safety feature for the user to use. In addition, copolymer is proven as the best material selection for safety syringe production.

\section{Acknowledgement}

The authors would like to thanks the Ministry of Higher Education for the funding of this project under the Prototype Research Grant Scheme TK01/UPM/02/1 (No. 5530400).

\section{References}

[1] Levin MV (2006), A new generation of disposable syringes. Biomedical Engineering 40(3), 140-143

[2] Sohn JW, Kim BG, Kim SH \& Han C (2006), Mental health of healthcare workers who experience needlestick and sharps injuries. Journal of Occupational Health 48(6), 474-479

[3] Alert N (1999), Preventing needlestick injuries in health care set tings. DHHS (NIOSH) Publication

[4] Canadian Centre for Occupational Health and Safety (2014), Needlestick and sharps injuries: OSH Answers. http://www.ccohs. ca/oshanswers/diseases/needlestick_injuries.html

[5] Steinglass R, Boyd D, Grabowsky M, Laghari AG, Khan MA, Qav A \& Evans P (1995), Safety, effectiveness and ease of use of a nonreusable syringe in a developing country immunization programme. Bulletin of the World Health Organization 73(1), 57-63

[6] Thye SL \& Bakri R (2007), Retractable needle syringe. Ministry of Health Malaysia.

[7] Hsieh H, Ho C \& Wang S (2005), Safety Syringe. Syriteck Medical Devices Co., Ltd. Patent No. US 6979314 B2

[8] Van Dyke LR (2002), Automatically Retractable Needle Safety Syringe. Patent No. US6413236 B

[9] Villanueva G (1999), Safety Syringe. Patent No. US 5938641 A

[10] Liu WN (1999), Safety Syringe with Retractable Standard Needle. Patent No. US 5899887 A

[11] Lee R (1994), Simple Retractable Safety Syringe. Patent No. US 5344403 A

[12] Walsh A (2010), Retractable Safety Syringe with Compressible Gasket Means. Global Medisafe Holdings Limited. Patent WO 2010096879 A1

[13] Mohd Zabidi SZ (2010), Design and Development of Safety Syringe. Thesis, Universiti Putra Malaysia.

[14] Basri AA (2011), Safety Syringe Product Development. Thesis, Universiti Putra Malaysia.

[15] Abu Talib AR, Basri AA, Mohd Zabidi SZ, Yahaya MS \& Mat Isa K (2011), Safety Syringe. Selia-Tek Medical Sdn.Bhd, Universiti Putra Malaysia. Patent No. US 20140171866 A1.

[16] Ishak MN, Abu Talib AR, Harmin MY \& Zahari R (2016), Design improvement of multi-purpose disposable safety syringe. World Research \& Innovation Convention on Engineering \& Technology

[17] Phase CD \& Step CE (2013), Conceptual Design Phase: Concept Evaluation Step, 1-40

[18] Oberdorfer PE (2000), Syringes - Latex and Silicone Oil in the Design and Manufacture of Disposable Syringes, 1-3

[19] Brendel CM (2009), Biocompatibility of polymer implants for medical applications. http://etd.ohiolink.edu/send-pdf.cgi/Brendel Christopher M.pdf?acc_num=akron1246892895

[20] Emco Industrial Plastics Inc. (2016), PP - Homopolymer. http:// www.emcoplastics.com/pp-homopolymer/

[21] Sepe M (2012), The Online Magazine of Plastics Technology: Plastics Technology. How Do You Like Your Acetal: Homopolymer or Copolymer? : Plastics Technology. http://www.ptonline.com/ columns/how-do-you-like-your-acetal-homopolymer-or-copolyme

[22] Richard Claudio AH (2004), Injection Pressures by Anesthesiologists During Simulated Peripheral Nerve Block. New York: US National Library of Medicine National Institutes of Health. 